\title{
Effectiveness of Visual Merchandising on Consumer Buying Behaviour: A Study of Reliance Digital, Puttur, DK
}

\author{
Shwetha Pai ${ }^{1}$, \& Sureshramana Mayya ${ }^{2}$ \\ ${ }^{1}$ Research Scholar, College of Management and Commerce, Srinivas University, Mangalore \\ - 575001, Karnataka, India. \\ ORCID-ID: 0000-0001-6312-1801; Email: shwetharahu198@gmail.com \\ ${ }^{2}$ Research Professor, College of Management \& Commerce, Srinivas University, Mangalore, \\ India \\ ORCID-ID:0000-0003-1951-0126; Email: sureshmayya@ hotmail.com
}

Area of the Paper: Business Management.

Type of the Paper: Research Case Study.

Type of Review: Peer Reviewed as per $|\mathrm{C}| \mathrm{O}|\mathrm{P}| \mathrm{E} \mid$ guidance.

Indexed In: OpenAIRE.

DOI: http://doi.org/10.5281/zenodo.5136832

Google Scholar Citation: IJCSBE

\section{How to Cite this Paper:}

Pai, Shwetha, \& Mayya, Sureshramana, (2021). Effectiveness of Visual Merchandising on Consumer Buying Behaviour - A study of Reliance Digital, Puttur, D.K. International Journal of Case Studies in Business, IT, and Education (IJCSBE), 5(2), 1-23. DOI: http://doi.org/10.5281/zenodo.5136832.

International Journal of Case Studies in Business, IT and Education (IJCSBE)

A Refereed International Journal of Srinivas University, India.

Crossref DOI : https://doi.org/10.47992/IJCSBE.2581.6942.0116

(C) With Authors.

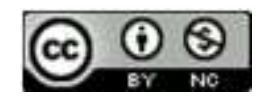

This work is licensed under a Creative Commons Attribution Non-Commercial 4.0 International License subject to proper citation to the publication source of the work.

Disclaimer: The scholarly papers as reviewed and published by the Srinivas Publications (S.P.), India are the views and opinions of their respective authors and are not the views or opinions of the S.P. The S.P. disclaims of any harm or loss caused due to the published content to any party. 


\title{
Effectiveness of Visual Merchandising on Consumer Buying Behaviour: A Study of Reliance Digital, Puttur, DK
}

\author{
Shwetha Pai ${ }^{1}$, \& Sureshramana Mayya ${ }^{2}$ \\ ${ }^{1}$ Research Scholar, College of Management and Commerce, Srinivas University, \\ Mangalore - 575001, Karnataka, India. \\ ORCID-ID: 0000-0001-6312-1801; Email: shwetharahul98@ gmail.com \\ ${ }^{2}$ Research Professor, College of Management \& Commerce, Srinivas University, \\ Mangalore, India \\ ORCID-ID:0000-0003-1951-0126; Email: sureshmayya@ hotmail.com
}

\begin{abstract}
Purpose: In this networked world, the buyer's purchase decisions are influenced by the arrangement and presentation of items in the store. Nowadays, the furniture and furnishing types have become more viable in the retail industry. Many new businesses are entering into the organized format of retail in this category. Hence the retailers need to differentiate themselves from each other. As the products are similar, it is necessary to differentiate themselves by presenting them with visual merchandising.

Objective: The core objective of this work is to study the influence of visual merchandising on consumer purchase patterns based on store attributes. Another objective of this study is to know the dimensions which influence the purchase behavior or decision of the consumers,

Design/Methodology/Approach: For this analysis, we have considered many online sources, namely websites and blogs, which guide and review display merchandising. Percentages, charts, diagrams are being used to present the tabular data.

Findings/Result: It is found that variables like store appearance, lighting, music, window display, mannequins, and price tags have an impact on the purchase choice of consumers, as per the changing need of consumer the retailer should always try to maximize the quantity of new merchandising relating to the trend. The store must adopt a congenial store atmosphere to attract a maximum number of customers and retain them in their business for long.

Originality/Value: Through the help of primary and secondary data, the study revealed that male youngster customers are more frequently visiting the store. The study reveals that the seating arrangement inside the store is not sufficient. The majority of the customer is visiting Reliance Digital to buy some specific product. Spot purchase activities are happening very rarely.
\end{abstract}

Paper Type: Visual Merchandising on Consumer buying behaviour at Reliance Digital is a case study analysis work.

Keywords: Visual merchandising, Consumer purchase, Competitors, Retail store, Store promotion, Display demo

\section{INTRODUCTION :}

The retail industry in India has emerged as one of the most dynamic and fast-paced industries accounting for more than 10 per cent of GDP and over eight per cent of the total employment. With several players entering the market, it became one of the most effective and fast-paced businesses. The Indian economy's retail sector is undergoing a massive shift.

The Indian economy's retail sector is divided into organised retail and unorganised retail, with the latter accounting for most of the retail market. The organised retail sector is currently catching up quickly. The influence of changes in the retail sector's format significantly impacts Indian customers' lifestyles. The massive rise in consumer activity has already carved out a money-making recess for the Indian economy's retail sector. The retail industry in India is the most important of all, accounting for 14-15 to 
$20 \%$ of the country's GDP. According to econometric estimates, the Indian retail sector is worth roughly US $\$ 500$ billion, making it one of the top five retail marketplaces in the world (Jasola, 2021; Sumathi, 2017) [1],[2]. The retail industry in India is expanding at a rapid pace, creating several opportunities for new entrants. However, in today's changing market, commercial success is quite challenging. Because entering the market necessitates a significant financial investment, gaining market share and competing with competitors is not as simple as the store may believe. The Indian market introduces a number of worldwide retailers. A large number of international retailers have entered the Indian market. During the year 2011-12, Indian organized retail was only seven per cent, now it is growing at a rate of 25\%, which is creating lucrative job possibilities (Phulia \& Sharma, 2014) [3] . The Indian retail industry is the largest of all industries, accounting for about $10 \%$ of the country's GDP and roughly $8 \%$ of employment. Food retailing in India dominates the shopping basket and is predicted to be valued at $\$ 175-200$ billion by 2016 . India's mobile phone retail market is already worth $\$ 16.7$ billion and increasing at a rate of over $20 \%$ per year. The word "retailer" has a long history. The word "retail" comes from the French word "retailer," which meaning "to break the mass" or "to take a portion off." The process of distributing items (products) for everyday usage by people is known as retailing. The sale of goods to the general public in modest amounts for personal use or consumption rather than resale.

\section{SCOPE OF THE STUDY :}

The study will cover the overall customer opinion survey on visual merchandising and its effect on their purchase. The study will be restricted to Reliance Digital (Mangalore-Madikeri Road) Puttur only. The study attempts to assist the company in finding out how they can increase market share. This study also aims towards knowing the customer opinion.

\section{OBJECTIVES :}

This research aims :

(1) To understand better the impact of visual or demo merchandising on consumer purchasing behaviour.

(2) To study the various components of visual merchandising at the retail stores.

(3) To understand the customer perceptiveness and expectations towards Reliance Digital retail stores.

\section{METHODOLOGY :}

The methodology is a way to solve the problem. The study is descriptive. It is an important component of the study, and it will help to solve the problem systematically. The methodology involves the research design, data collection and sample technique.

- Primary Data: Primary data are directly collected from the respondent's with the help of a questionnaire, discussion with consumers and the organization.

- Secondary Data: Efforts are made to collect information about the industry and, in particular, our research unit through the journals, magazines, company profiles, internet and company records.

- Statistical tool: Simple percentages and diagrammatic representation are being used.

- Location of the study: Study will be conducted in Reliance Digital, Puttur.

\section{LITERATURE REVIEW :}

In Sanjita Bista, (2018) [4] thesis attempted to determine the relationship between visual merchandising and the store management and the customer in the Physical Retail Industry. This study focuses on upcoming challenges which retail stores daily face. The authors focused on the various challenges like display window, visual merchandising elements, the benefit getting by the store manager from these tools. In the article of Saumya Sinha, (2018) [5] on Visual Merchandising in the Digital World, the researcher explains visual merchandising strategies and social media to entice customers. The display of some of those stores radically changed the way of presentation of items. The language of retail can be seen, touched and even felt. It is not just about showcasing the products that could sell but about presenting them with edges of props and under the store's staff, at the art of lighting to create striking windows that mirror the dreams and desires of today's customers. Even Law et al., (2012) [6] aim to explore consumer affective response on visual stimulus in-store by considering the aesthetic, symbolic and cultural perceptions and visual merchandising elements such as colour. 
The researchers Randhawa \& Saluja, (2017) [7] explore consumer impulse buying behavior, which is influenced by visual merchandising. In India, the importance of visual merchandising has been overlooked. However, in the last five years, it has caught the attention of young people and is assisting merchandisers in overcoming the challenge of attracting clients to their businesses. The culture of shopping behavior of consumers through malls and complexes is growing in leap bounds in Punjab. The research aimed to address the peculiar dilemma faced by the merchandiser for effective visual merchandising cues directed towards the customer attraction towards stores. The authors Soomro et al., (2017) [8] explains that visual merchandising is a tool that helps to make a brand visually more attractive and highlight stores unique features. These brands are usually focused on visually enhancing brand, and it aims to provide a better shopping experience for a long period of time.

Khan \& Kumar, (2016) [9] argued that visual marketing features include product display, store ambience, floor merchandising, promotional strategy, and discount signage board. The authors Zulaikha Fatima et al., (2017) [10] have thrown light on the emerging area of retailing in their research work. According to their work, technology is supposed to motivate retailers and smartphones act as a blessing in disguise for the retailer, and they have revolutionized the entire shopping experience in the present time. Internet, mobile apps, scan-and-go technology have changed consumer expectations and enabled them to connect to their targeted audience. Dale, (2017) [11] narrates that the effectiveness of visual merchandising can be measured with the help of two retail math formulas. They are attributing towards visual merchandising and visual merchandising association. The remaining scale item was retested and found to be loading a single factor. The participants were exposed to one of eight different conditions involving the combination of the three variables: store type, signage type, and visual display level; the results indicated no interaction effects of store type and visual merchandising on shopper response. Chang et al., (2014) [12] guided by Stimulus-Organism-Response (S-O-R) model, investigated the direct and indirect effects of apparel store environmental characteristics and consumers positive emotional responses to the environment on impulse buying behaviour. The study found that managing appealing store design characteristics may increase consumers positive emotions and impulse purchases. The researchers (Tumbe \& Krishnakumar, 2018; Upadhyay et al., 2017) [13] [14] concluded that reshaping changes business spheres. Service innovation like home delivery, the recreation of the bazaar atmosphere shape individual success in modern retailing. They felt that the variety and emergence of new techniques increased the vibrancy in the overall business environment with growing complexity. Contrary to an older time, shopping is not need-based and product-centric. Due to the increased range of products and developed customer attitude, display of the product is also essential. To fetch the customers' attention, retailers started spending more money on the concept of VM (Visual Merchandise). Customers are price sensitive and focus on product attributes. Changing customer attitude and proper display of merchandising presentation holds the attention of the seller.

The author's Saif \& Aimin, (2016) [15] explained that marketing strategy represents an essential element for the success of organizations. Conceptualizing and creating a marketing strategy with the help of scarce resources is vital to attain the set goals and targets. The authors conducted a metaanalysis of two distinct but related features to marketing strategy content, marketing strategy decisions, and decision implementation. Long term plan is important to reposition a product and make it more acceptable to a new group of customers. The authors linked a prepared theoretical model with standardization adaptation of international marketing strategy with the company performance. They tried to link the adaptation of international marketing strategy with the company performance. Logkizidou, (2016) [16], in his doctoral thesis, discusses how visual merchandising can increase customer intention to buy luxury brands and have a more significant influence on consumer cultural capital than those with lower cultural capital. The contemporary research in luxury retailing literature explores product presentation techniques in building and sustaining the brand image. His theory explains the input of Visual Merchandising Display on consumer purchase intention and the moderating role of cultural capital.

The authors Kiran \& Mridula, (2015); Saeed, (2015) [17][18] explained the importance of visual merchandising in today's world, it cannot be ignored since store displays, and marketing presentations influence most consumer decisions. At the same time, Kiran \& Mridula focused on the importance of visual merchandising in toys and how it will affect the customer's behaviour, while the study of Saeed's primary goal is to determine the impact of lighting as a subject matter of visual merchandising in attracting the consumer's attention to a certain area of purchase and a specific store location, as well as 
to comprehend the consumer's behaviour. Before and after, the method of experimentation was used to know the impact of lighting in influencing the consumer to purchase and visit the particular storage area. The study found a positive effect of light to attract the consumer mind to visit the store, and an increase in shoppers' traffic was also noted.

Kumar \& Kim, (2014) [19] focused that despite their significance within the fashion industry, now a day's retailer selling their brand of fashion material (single brand apparel retailers) has not examined the connection between their store atmosphere and customer responses. The study revealed the store atmosphere on customer internal evaluation and behaviour regarding a single brand fashion retailer to understand whether customers have similar cognitive and affective perceptions toward the store versus merchandise. They conducted a mall intercept survey, and a non-recursive structural equation model was employed to test the proposed hypotheses. That study found that social, design and ambient cues and merchandise cues influenced internal evaluations and concluded that the store-as-a-brand concept is valid for a single brand product. Roxana \& Ioan, (2013) [20] presented the extended literature review of relevant empirical studies that examined consumer perception, consumers emotions and consumers behavioral responses in connection with retailing. The authors concluded that other atmospheric stimuli, such as background music, ambient scent, etc., received little attention from researchers. Their paper presented a complex conceptual framework on the influence of ambient scent on consumer responses. The study of Mari \& Poggesi, (2013) [21] aimed at filling the gap with a systematic literature review based on rigorous criteria, and they reviewed the 188 papers and made an in-depth analysis of new research paths on the topic. Their research findings contributed to a link between customer behaviours and new ways of interpreting specific features of the services cape. Murray et al., (2019) [22], depending on aesthetics literature, examined how novelty, unity and variety help to explain consumers' aesthetic pleasure and avoidance behaviour. The authors comparatively studied consumers' perceptions of actual store designs in a recently remodelled fashion store and an older store prototype. Their findings established that novelty, variety rendered aesthetic pleasure compared to the older store.

The study of Pillai et al., (2011) [23] used the survey method, and data were acquired through sampling from specific respondents. The significant finding in the context of the store has to maintain an attractive display window; adequate store layout is the most critical aspect of all visual merchandising. The store has to maintain attractive lighting and an attractive display theme. The result of the study uncovered that the display appeal has to be updated as per the changing trend. El-Gohary, (2010) [24] aimed to build a marketing review on E-marketing. His literature provided an archive of past research points and the methodology relating to e-marketing emergence - interpretation and development of proper understanding about the various research topic and ideologies implemented in E-Marketing articles.

All the above studies stressed the need to implement an appropriate visual marketing plan keeping in view of required aesthetic, symbolic and cultural perceptions of customers. A different perspective on visual merchandising is offered depending on the product category. The existing literature tends to focus on the interaction between individual visual merchandising elements and consumers. All the existing literature tried to focus on various product categories, but not on mobile phones. There is a dearth of information about visual merchandising in the digital and cell phone category. This research is mainly focused on the importance of visual merchandising of all digital products such as laptops, mobile phones, audio products and other related products and how it will affect the customers or consumers behaviour. Retailers in designing their stores can use this information. This study will focus on Indian customers behaviour. This research will be necessary for visual merchandising in digital products and the things that a digital retailer should focus on during store design.

\section{INDUSTRY OVERVIEW OF RELIANCE DIGITAL :}

Reliance Digital offers more than 200 national and international brands. They have been offering a large variety of products spanning digital cameras, music \& video products, durables like washing machines, air conditioners, refrigerators, gaming consoles \& games, laptops, tablets \& peripherals, mobile, computers, microwave ovens, water purifiers, kitchen and home appliances, fixed-line instruments, as well as a wide selection of accessories and new-age gadgets. Reliance Digital provides its customers with pleasurable shopping experiences by allowing them to purchase the new advanced home and innovative technology items at unbelievable prices. (Reliance Retail, n.d.)

The company aims to provide better value for money. The company focuses on buying only those products that demonstrate exemplary safety and durability products such as products involving quality 
standards like ISI, FPO, CE Mark, RU marks are considering at the time of buying the product. Reliance Digital has also been offering a homogeneous mix of branded and private label branded products. The industry will focus on reaching the target of middle-class consumers in the country. The company is offering affordable services to end-users. Reliance focuses on delivering good quality to consumers, affordability of buying, and having good supply chain support. Reliance Digital always welcomed suggestions from the customer and tried to learn from the customer and implement it.

\section{Subsidiaries \& Division :}

There are over 45 Subsidiaries \& divisions of Reliance Retail

(1) Reliance Fresh is a supermarket that sells fruits, vegetables, and groceries.

(2) Reliance SMART- Reliance Smart provides its customers with a one-stop shopping experience by offering a wide range of fresh fruit, bakery, home and personal care items, dairy products, and general commodities.

(3) Reliance LYF: 4G mobile handset manufacturer based in Mumbai, founded in 2015.

(4) Reliance Jewels: Jewellery retail; it had revenues of approx. Rs. 8 billion in the financial year 201213.

(5) Apparel \& Clothing: Reliance Trends, Reliance Footprint, and Reliance Living It made almost Rs. 15 billion in revenue in the financial year 2012-13, with 288 stores.

(6) Apparel \& Clothing: Reliance Trends, Reliance Footprint, and Reliance Living It made almost Rs.

15 billion in revenue in the financial year 2012-13, with 288 stores.

(7) Reliance Retail has the distinction of operating the largest consumer electronics store chain in India through a network of over 8,000 Reliance Digital and Jio stores

(8) One of the company's earliest online e-commerce websites was Ajio.

\section{Background of the Company}

Reliance Digital store was established on 24-April-2007 founded by Dhirubhai Ambani, a starting sound in the Retail Industry in the Global market leader. He became an icon for the whole enterprise in India in the late 1970s. Reliance Digital in Puttur was opened in 2016. It currently has 29 employees with an area of 18,000 Sq Ft. Reliance Digital covering the Puttur city for its area of operation. Reliance retail delivering value for both internal as well as external stakeholders through its functional activities. Reliance group of businesses having their strategic policies, which are followed by all of its subsidiary outlets. These policies will help to achieve to reach the target goal.

\subsection{VISION, MISSION AND QUALITY POLICY OF RELIANCE DIGITAL Vision \\ - To make reliance retail in world largest innovative market \\ - Personalising the technology \\ - Increase in growth of profit earning.}

\section{Mission}

Differentiated customer experience and establishing an ongoing relationship by creating values through personalised service.

\subsection{QUALITY POLICY}

Reliance management is focusing on committing customer needs and desires and statutory and regulatory requirements by following and supporting various procedures, including the technical procedure of ANSI Z359 code of fall protection and product quality protection of ISO 17025.

\section{Reliance Digital is committed to-}

- Assuring quality

- Provides access to clients witnessing, testing where required

- Maintain the confidentiality of records of testing and client's information

- Exceeding both products as well as service expectation and meeting the quality requirement of their internal and external client through providing all round training requirement 
- Reporting non-conformance to procedures and/ processes immediately

Product profile

The various products which are available at the Reliance Digital stores are -

- Kitchen and home appliances

- Audio and home appliances

- Digital cameras

- Refrigerator

- Washing machines

- Micro oven

- Water purifiers

- Gaming consoles\& Games

- Computer, laptop and peripherals

- Mobiles

\section{Branded products}

The Reliance Digital offering various types of branded products are mentioned below-

Sony, Samsung, Apple, Google pixel, H.P, Dell, Honour, Mac book, Hi-tech, Whirlpool, IFB, Bosch, Philips, Panasonic, Futura, Redmi, Yamaha, Asus

\section{Non-Branded items}

Reliance Digital marketing certain private label products under its own brand called 'Reconnect'. These products offer brand warranty varies up to 6 months to 1 year.

\section{Area of operation}

The Reliance group of the companies are extended its various branches in metropolitan and express cities like Delhi, Maharashtra, Karnataka, and Tamilnadu. Currently, it is having more than 1900 branches operating in India.

The company having Corporate Head Office at Mumbai, Maharashtra with many regional offices.

\section{Infrastructural facilities}

Reliance Digital stores have state-of-the-art infrastructure facilities in all of its outlets. It provides excellent infrastructural facilities by keeping in mind customer attraction towards the product and highlighting its features. Reliance Digital store in Puttur provides a prominent parking place, drinking water facility, and customer baggage counter. The store has three floors, and on each floor of the store, the merchandising is divided based on customer convenience for easy access and by keeping in mind the technique used to present the visual merchandising tool. An effort will be made to make a SWOT Analysis of Reliance Digital.

\subsection{SWOT ANALYSIS}

SWOT analysis is a methodology for assessing a company's competitive position by determining its strengths, weaknesses, opportunities, and threats. SWOT analysis is a fundamental evaluation methodology that analyses what a company can and cannot do and prospective opportunities and threats [25-29].

\section{Strengths}

Strength is the internal potential of any organization or firm. The stores have control and alter this strength which can be effectively used for competitiveness. Some of the strengths are listed below

- Reliance Digital have an excellent financial position

- Reliance retail offering high-quality products

- Live demo and touch and feel the experience in every reliance Digital store

- Reliance Digital has a good brand image

- Reliance Digital has a good customer support service

- Reliance Digital have very good technical as well as non-technical staff.

\section{Weakness}

Any resource or procedure that your company lacks, as well as your company's capacity to attain its full potential, is a company weakness. As part of their strategic planning process, companies frequently assess their weaknesses. The major weakness of Reliance Digital are: 
- Delay in goods delivery process.

- They are incurring huge expenditures on employee training.

- Inadequate warehouse facility

- The store does not have its own trading area

- Necessary Improvement is required in visual merchandising inside the store.

- Some of the customers are visiting the store with the purpose of window shopping.

\section{Opportunities}

Opportunities are factors that can contribute to the firms growing success. These factors are typically outside of the companies' control, which is why they are considered external factors.

- Reliance staff members have excellent career opportunities

- Customers have opportunities to access the goods easily

- The Reliance has very good support from financial institutions.

- Flexible working hours

- Reliance Digital staff workers have a separate identity as compared to other competitors.

\section{Threats}

Threats refer to the factor that have potential to harm an organisation. some of the major threats which are facing by the Reliance Digital Puttur branch are-

- Reliance Digital is facing tough competition from other rival stores in Puttur city.

- Affected by the government policies

- Difficult to follow the rules framed by the upper head.

\section{Future Growth and Prospects}

- Reliance Retail has reported a revenue of Rs 1,53,818 crore and a pre-tax profit of Rs 9,842 crore in FY21 (Business Standard)

- Reliance retail wants to improve the online sale of smartphones and electronic goods.

- Reliance Digital want to cut down its cost of production through adopting modern technology and selling product at a lower price.

\section{DATA ANALYSIS AND INTERPRETATION :}

In this section, various charts are drawn based on the primary data, and the same is interpreted in different ways. Table 1 shows the age limit of respondents with the Number of Responses and Percentages. Table 1 shows how people come to know about the store.

Table 1: How people come to know about the store

\begin{tabular}{|l|c|c|}
\hline \multicolumn{1}{|c|}{ Media information } & Respondents & Percentage \\
\hline Newspaper & 10 & $20 \%$ \\
\hline Radio/FM & 09 & $18 \%$ \\
\hline Word -of-mouth & 21 & $42 \%$ \\
\hline Television & 10 & $20 \%$ \\
\hline Total & 50 & $100 \%$ \\
\hline
\end{tabular}




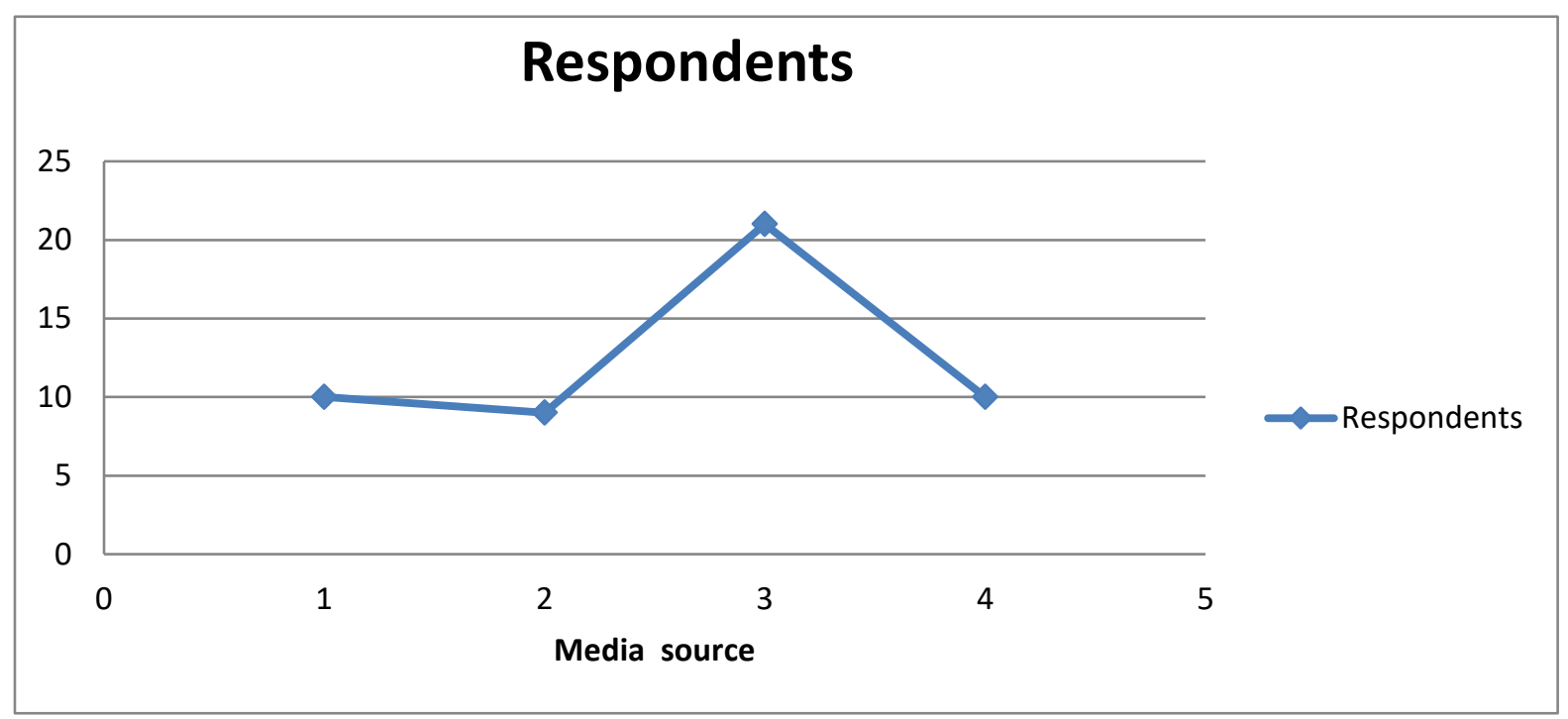

\section{Interpretation}

Fig. 1: Media which helps people come to know about the store

Figure-1 shows that out of 50 respondents, $20 \%$ of people came to know about the store through Newspaper, $18 \%$ of people know about the store through F.M, word of mouth is in the highest position of $40 \%$, T.V impact on the consumer are $20 \%$. Table 2 shows Respondent's opinion regarding spot purchase from the store

Table 2: Respondents opinion regarding spot purchase from the store

\begin{tabular}{|l|c|c|}
\hline Opinion & No of respondents & Percentage \\
\hline Yes & 14 & $28 \%$ \\
\hline No & 7 & $14 \%$ \\
\hline Cannot say & 29 & $38 \%$ \\
\hline Total & 50 & 100 \\
\hline
\end{tabular}

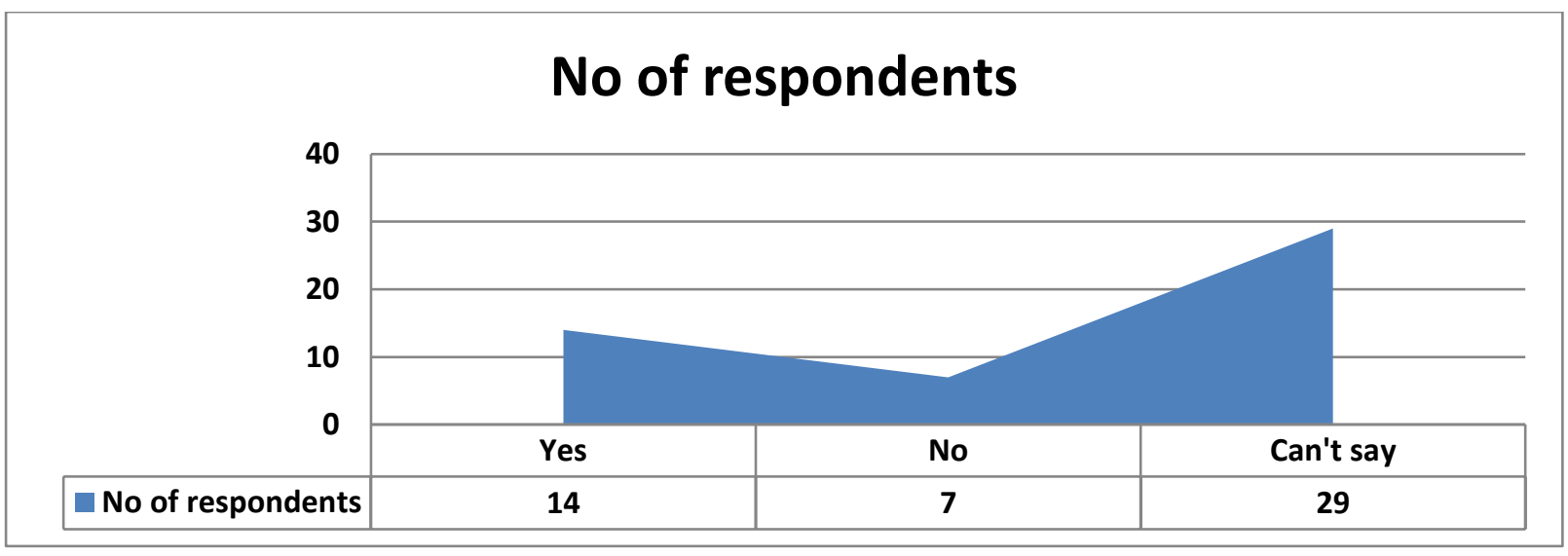

Fig. 2: Respondents opinion towards spot purchase from the store 


\section{Interpretation}

In above Figure-2, out of 50 respondents, 14 respondents are visiting the store with the purpose of spot purchase, and 7 respondents have mentioned their decision as No and 29 respondents said they could not say about their spot purchase decision. Table 3 shows the Consumer rating towards the impact of Visual Merchandising for the consumer durable electronic category.

Table 3: Consumer rating towards impact of Visual Merchandising for consumer durable electronic category

\begin{tabular}{|l|c|c|}
\hline Rating & No of Respondents & Percentage \\
\hline Not important & 6 & $12 \%$ \\
\hline Little Important & 12 & $24 \%$ \\
\hline Very Important & 15 & $30 \%$ \\
\hline Highly Important & 17 & $34 \%$ \\
\hline Total & 50 & $100 \%$ \\
\hline
\end{tabular}

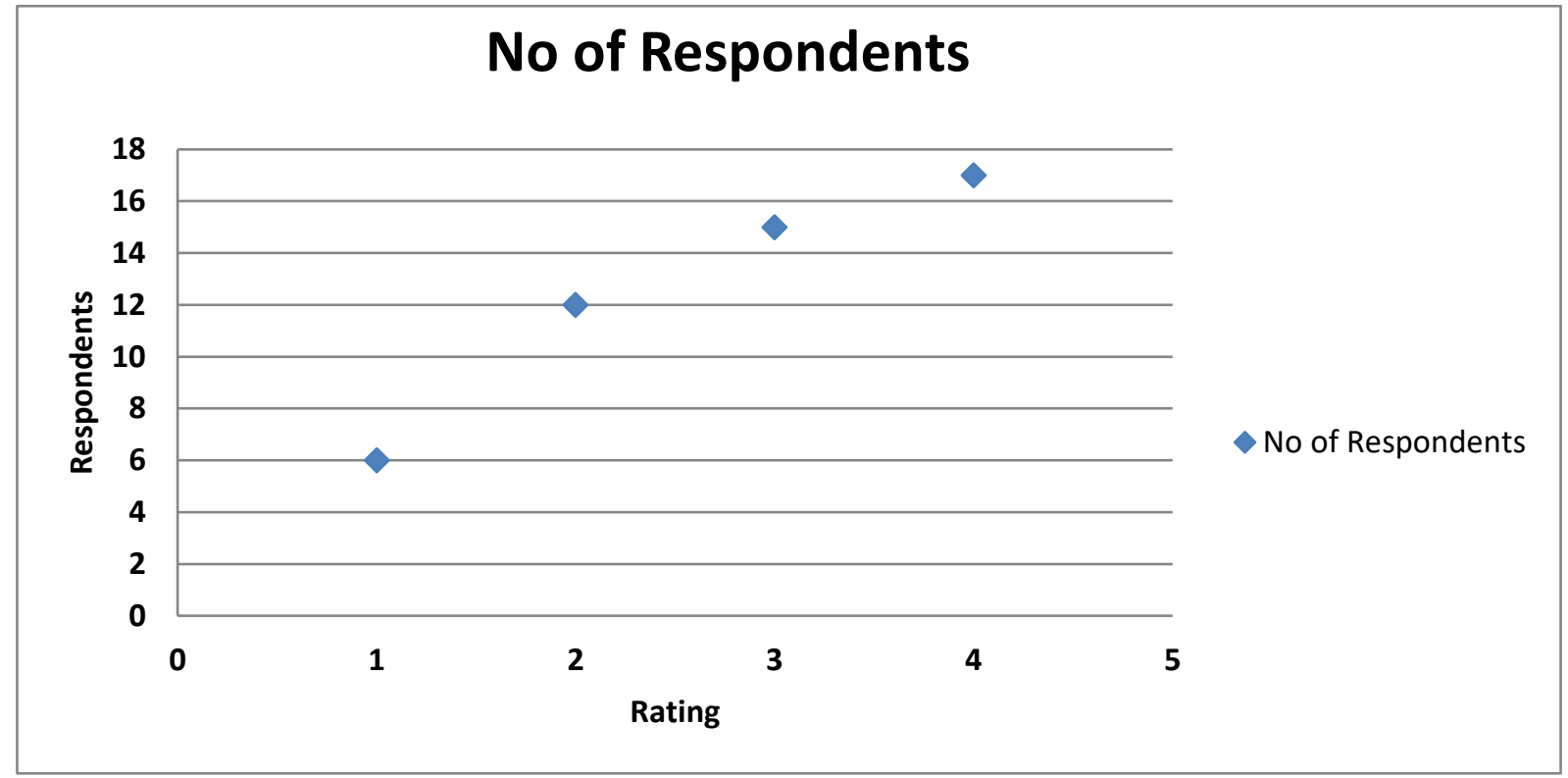

Fig. 3: Consumer rating towards the impact of Visual Merchandising for consumer durable electronic category

\section{Interpretation}

From the above Figure-3, it is clear that out of 50 respondents, $34 \%$ of respondents believed that the impact of Visual Merchandising is significant for consumer durable electronic category store, $30 \%$ of respondents agreed as very important, and $24 \%$ of respondents have believed that VM has little impact on the presentation of good and $12 \%$ of respondents are advised that the VM has no impact on the presentation of consumer durable electronic items. To sum up, the majority of respondent's felt that Visual Merchandising has a high impact on the consumer to buy the merchandising. Table 4 shows which facility should be improved inside the store. 
International Journal of Case Studies in Business, IT, and Education (IJCSBE), ISSN: 2581-6942, Vol. 5, No. 2, July 2021

Table 4: What facility inside the store is to be improved

\begin{tabular}{|l|c|c|}
\hline Particulars & No of respondents & Percentage \\
\hline Sitting arrangement & 14 & $28 \%$ \\
\hline Trial counter & 9 & $18 \%$ \\
\hline Ventilation & 18 & $36 \%$ \\
\hline Discount Signage & 9 & $18 \%$ \\
\hline Total & 50 & $100 \%$ \\
\hline
\end{tabular}

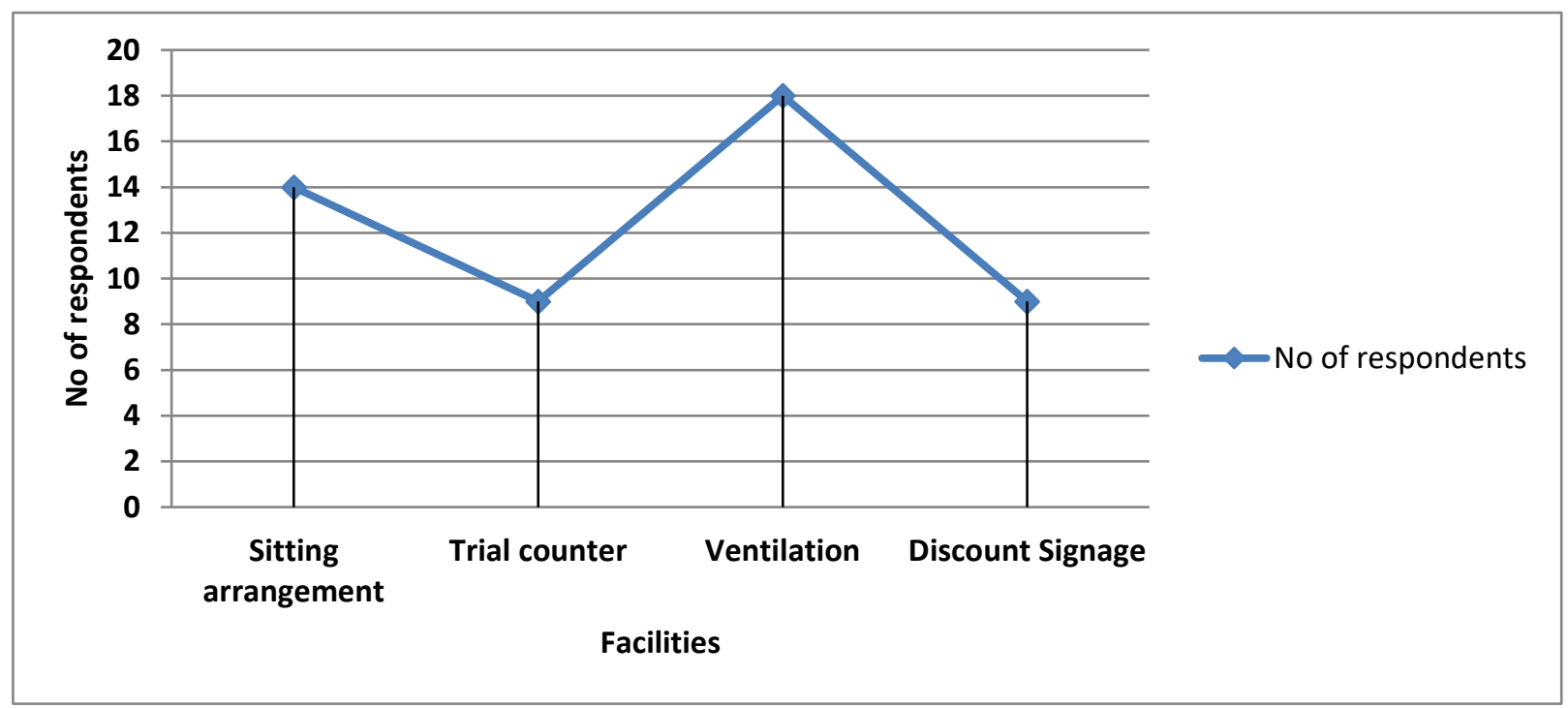

Fig. 4: what facility inside the store is to be improved

\section{Interpretation}

From the above Figure- 4 it can be observed that $36 \%$ of respondents have not satisfied with the ventilation inside the store, $28 \%$ of respondents' were not felt comfortable in the sitting arrangement, 9\% of respondents were not feeling satisfied with existing Trial/ Demo counters, and 9\% not satisfied about discount signage boards. The Table 5 shows the various elements of the visual merchandising.

Table 5: Customer perception about store lighting

\begin{tabular}{|l|c|c|}
\hline Particulars & No of respondents & Percentage \\
\hline Excellent & 36 & $72 \%$ \\
\hline Satisfactory & 10 & $20 \%$ \\
\hline Average & 4 & $8 \%$ \\
\hline Total & 50 & $100 \%$ \\
\hline
\end{tabular}




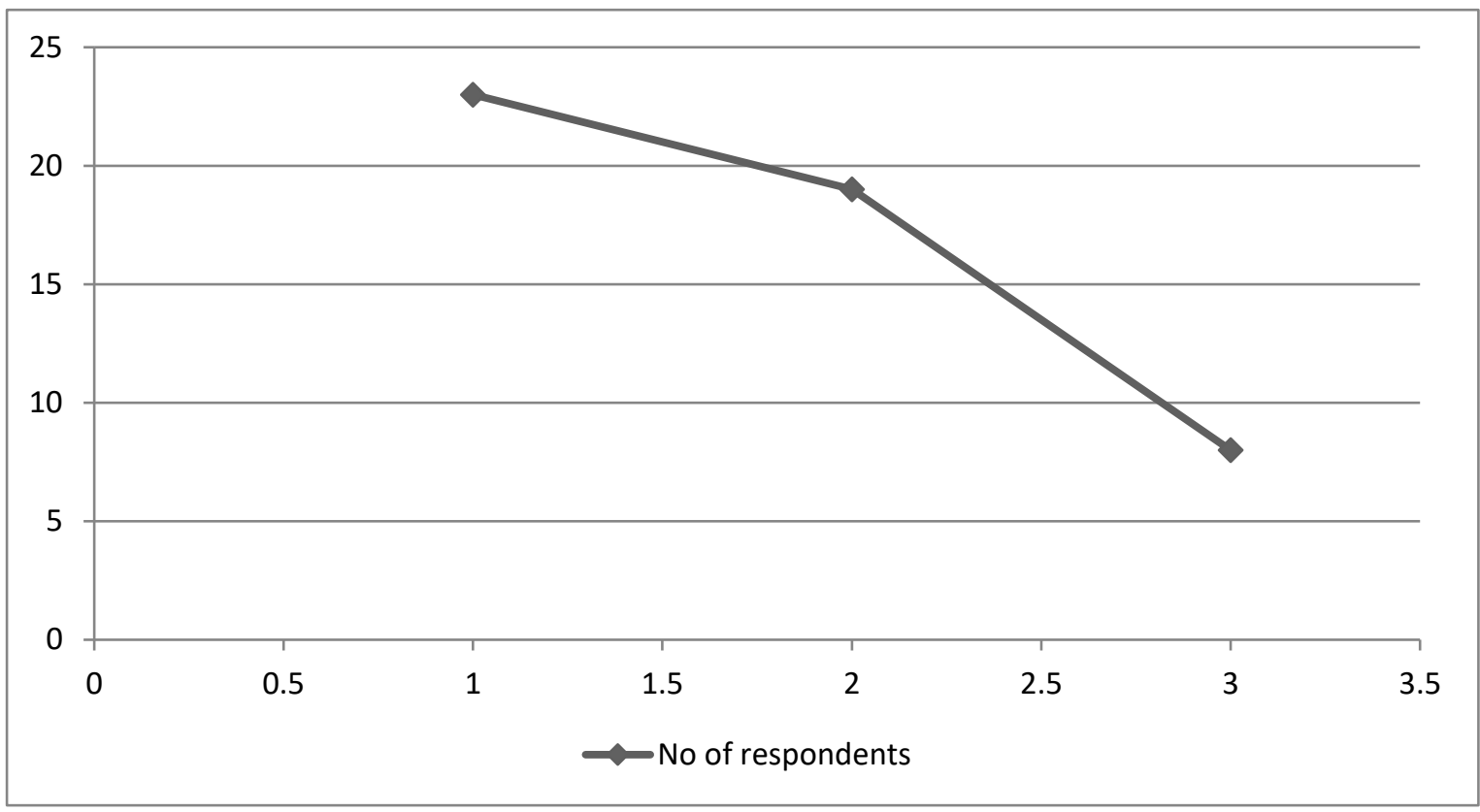

Interpretation

Fig. 5: Customer perception about store lighting

From the above Figure-5, it is clear that the information obtained through a questionnaire - out of 50 samples, $72 \%$ of respondents have mentioned their opinion regarding store lighting as excellent, $20 \%$ of respondents were satisfied, and $8 \%$ of respondents mentioned their opinion regarding store lighting as average. Table 6 shows customer perception about store cooling.

Table 6: customer perception about store Cooling

\begin{tabular}{|l|c|c|}
\hline Particulars & No of respondents & Percentage \\
\hline Excellent & 23 & $46 \%$ \\
\hline Satisfactory & 19 & $38 \%$ \\
\hline Average & 8 & $16 \%$ \\
\hline Total & 50 & $100 \%$ \\
\hline
\end{tabular}




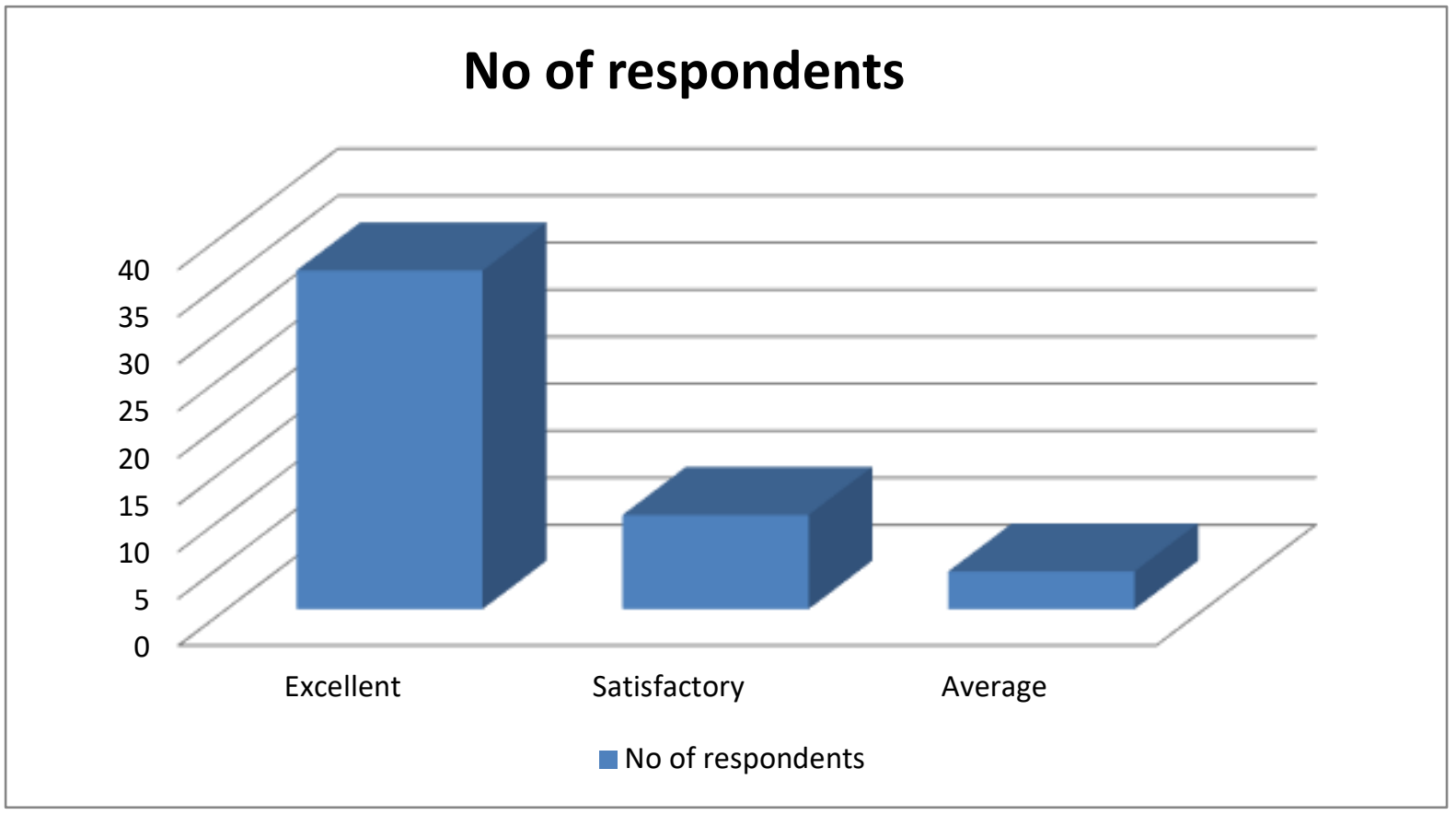

Fig. 6: Customer perception about store cooling

\section{Interpretation}

From the above Figure- 6 , it can be observed that $46 \%$ of respondents are agreed that the store cooling system is excellent, $38 \%$ of respondents are agreed store cooling system is satisfactory, and $16 \%$ of respondents are mentioned their opinion as average. Table-7 shows customer perception about store Staff assistance.

Table 7: Customer perception about store Staff assistance

\begin{tabular}{|l|c|c|}
\hline Particulars & No of respondents & Percentage \\
\hline Excellent & 19 & $38 \%$ \\
\hline Satisfactory & 20 & $40 \%$ \\
\hline Average & 11 & $22 \%$ \\
\hline Total & 50 & $100 \%$ \\
\hline
\end{tabular}




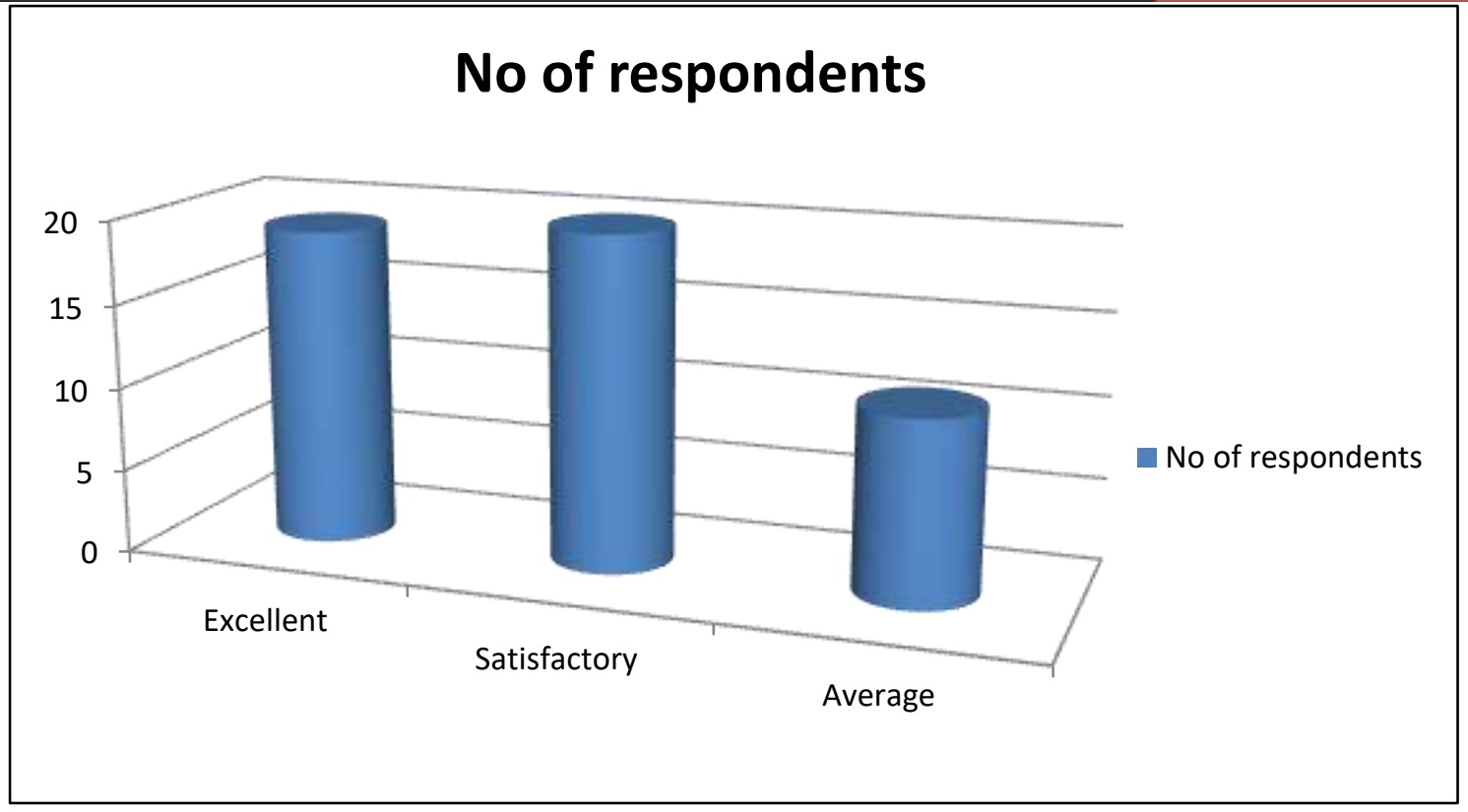

Fig. 7: Customer perception about store staff assistance

\section{Interpretation}

From the above Fig.7, out of 50 respondents, $38 \%$ of respondents agree that staff assistance is excellent, $40 \%$ of respondents agree as satisfactory, and $22 \%$ of respondents are mentioned their opinion as average regarding staff assistance. Table 8 shows customer perception about store Hygiene.

Table 8: customer perception about store Hygiene

\begin{tabular}{|l|c|c|}
\hline Particulars & No of respondents & Percentage \\
\hline Excellent & 19 & $38 \%$ \\
\hline Satisfactory & 23 & $46 \%$ \\
\hline Average & 8 & $16 \%$ \\
\hline Total & 50 & $100 \%$ \\
\hline
\end{tabular}

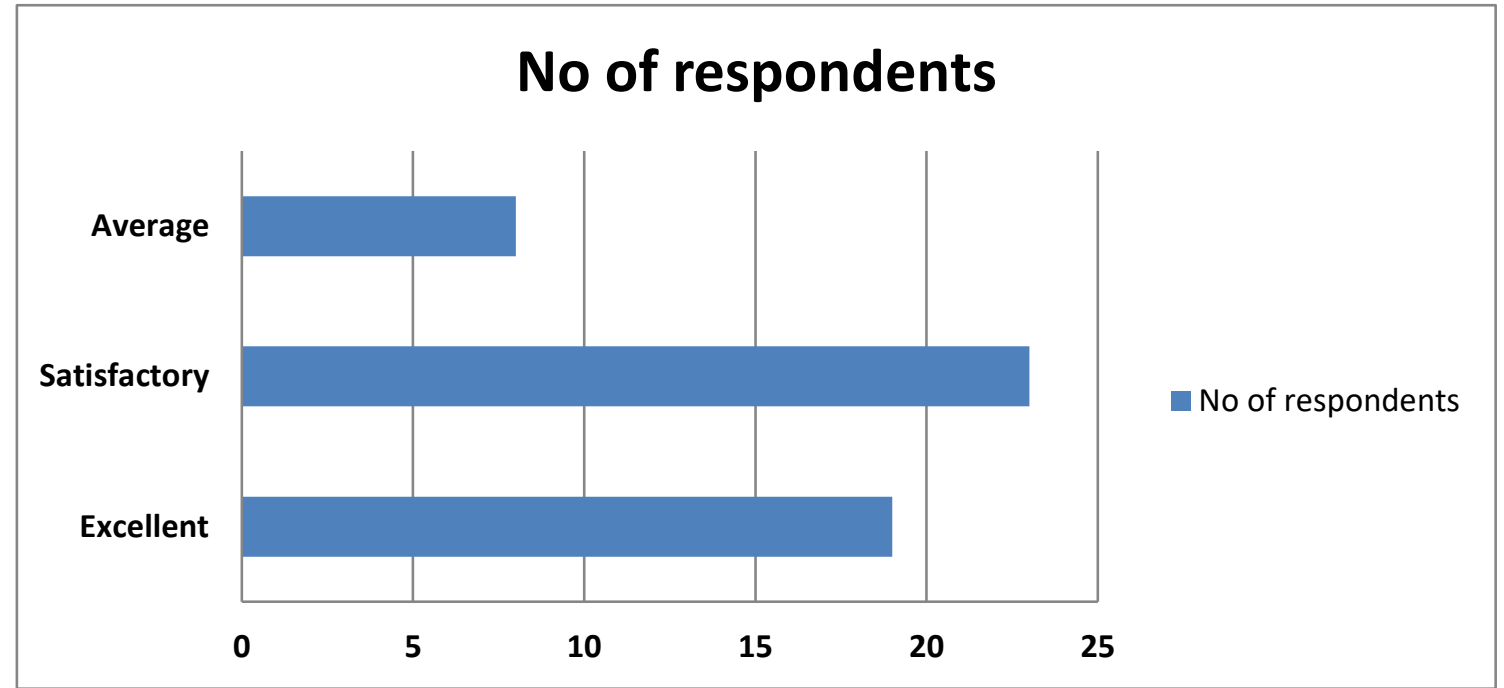

Fig. 8: Customer perception about store Hygiene

\section{Interpretation}

From the above Figure- 8 , it is clear that out of 50 respondents, $38 \%$ of respondents are agreed their opinion relating to the cleanliness of the store are excellent, $46 \%$ of respondents are agreed as 
satisfactory, and $16 \%$ of respondents' highlights their opinion regarding the store cleanliness as average. From the above analysis, it is clear that the store must concentrate on store hygiene. Table-9 shows customer perception about store Music inside the store.

Table 9: Customer perception about store Music inside store

\begin{tabular}{|l|c|c|}
\hline Particulars & No of respondents & Percentage \\
\hline Excellent & 25 & $50 \%$ \\
\hline Satisfactory & 22 & $6 \%$ \\
\hline Average & 3 & $44 \%$ \\
\hline Total & 50 & $100 \%$ \\
\hline
\end{tabular}

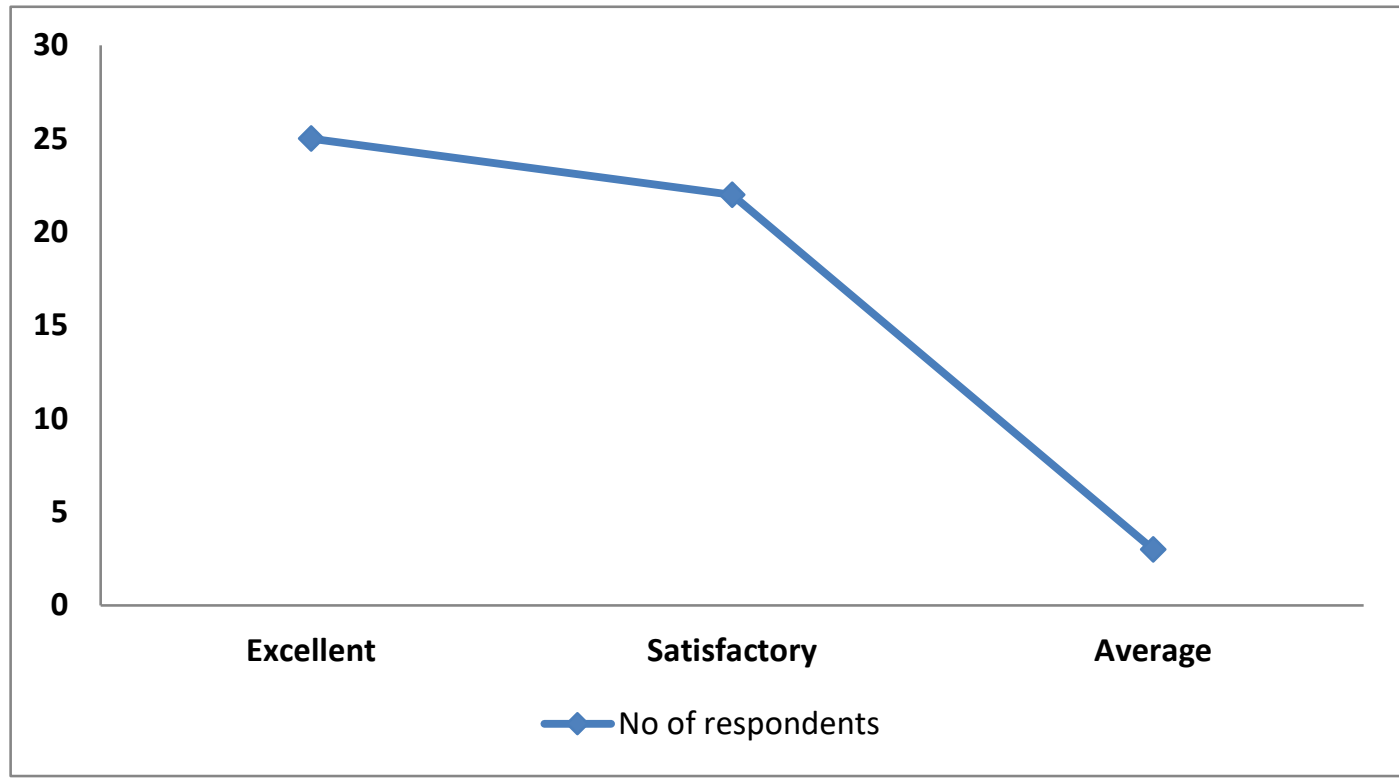

Fig. 9: Customer perception about store music inside store

\section{Interpretation}

From the above Figure-9, it can be observed as out of 50 samples, $25 \%$ of respondents agree that the store music system is excellent, $6 \%$ of respondents are satisfied, and 3\% of respondents agree to store the music system as average. Table 10 shows customer rating towards of the store.

Table 10: Customer rating towards of the store

\begin{tabular}{|l|c|c|}
\hline \multicolumn{1}{|c|}{ Particular } & No of respondents & Percentage \\
\hline Average & 14 & $28 \%$ \\
\hline Good & 18 & $36 \%$ \\
\hline Very good & 7 & $14 \%$ \\
\hline Excellent & 11 & $22 \%$ \\
\hline Total & 50 & $100 \%$ \\
\hline
\end{tabular}




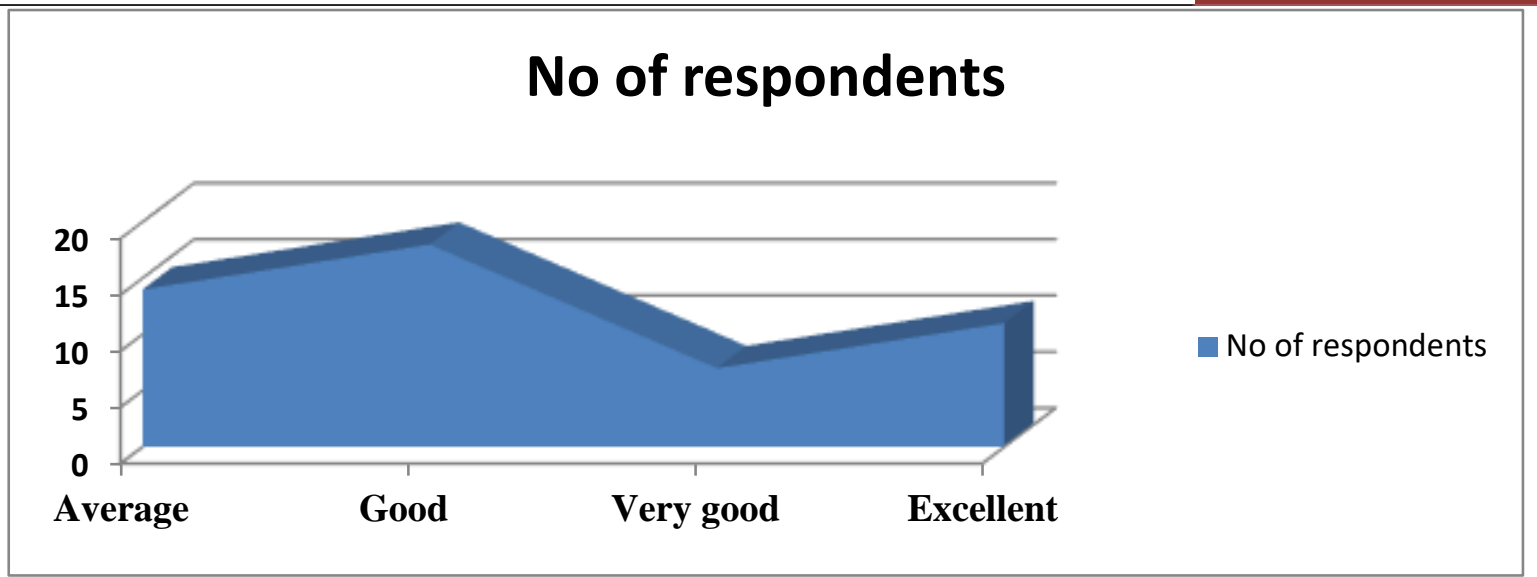

\section{Interpretation}

Fig. 10: Customer rating towards of the store

From the above Figure-10, out of 50 respondents, $36 \%$ of respondents agreed that the outer look of the store is good, $28 \%$ of respondents agree that good, $22 \%$ of respondents have believed excellent, and $14 \%$ of respondents agreed that the outer look of the store was perfect. From the above analysis, it should clear that outer look of the store is needed to improve. Table 11 shows the helping nature of the store personnel to their customers

Table 11: Helping nature of the store personnel to their customer

\begin{tabular}{|l|r|r|}
\hline Particulars & No of respondents & Percentage \\
\hline Highly satisfied & 9 & $18 \%$ \\
\hline Satisfied & 32 & $64 \%$ \\
\hline Average & 6 & $12 \%$ \\
\hline Bad & 3 & $6 \%$ \\
\hline Total & 50 & $100 \%$ \\
\hline
\end{tabular}

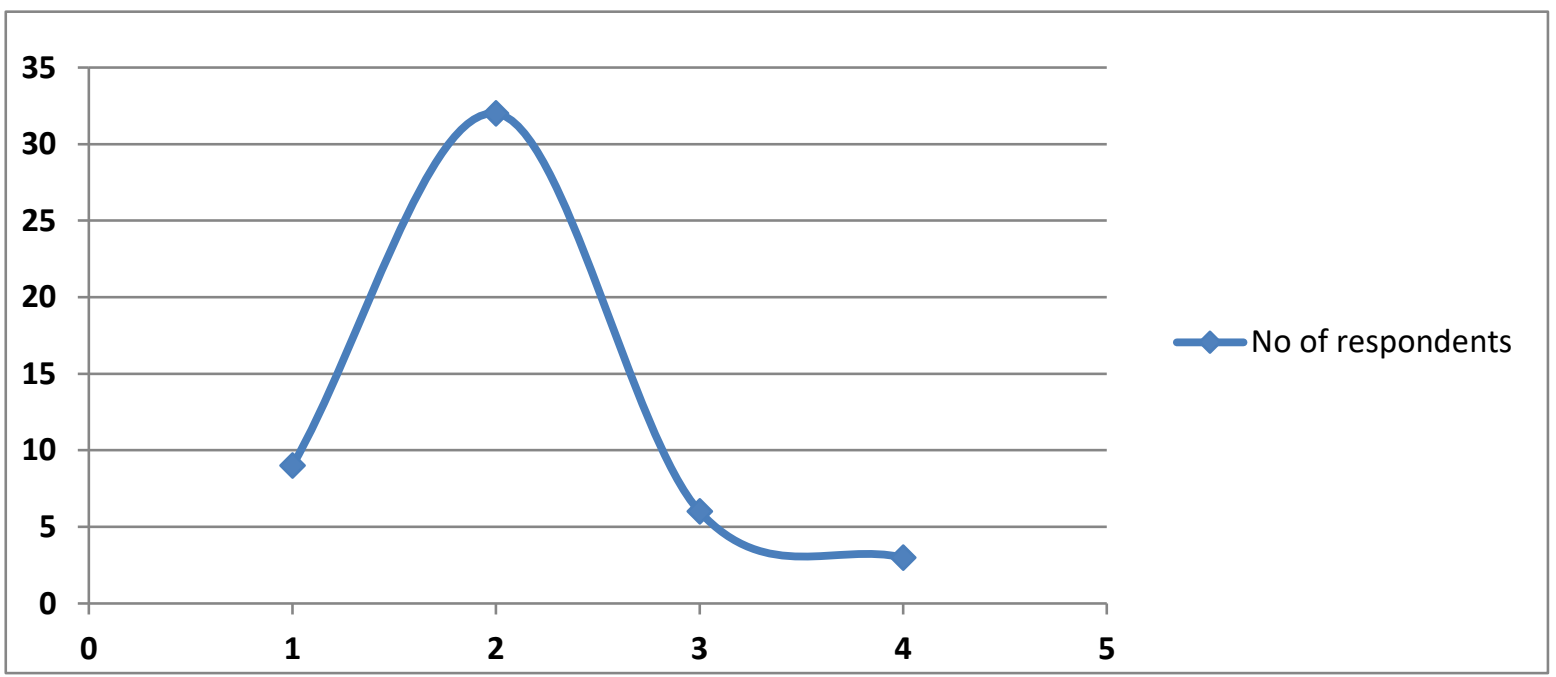

Fig. 11: Helping nature of the store personnel to their customer

From the above Figure-11, it is clear that out of 50 samples, $64 \%$ of respondents are satisfied, $18 \%$ of respondents are highly satisfied, $12 \%$ of respondents agrees that the store helping nature are average, and $6 \%$ of respondents believes that Bad. Table 12 shows the product knowledge of sales personnel. 
International Journal of Case Studies in Business, IT, and Education (IJCSBE), ISSN: 2581-6942, Vol. 5, No. 2, July 2021

Table 12: Product knowledge of sales personnel

\begin{tabular}{|l|c|c|}
\hline Particulars & No of respondents & Percentage \\
\hline Highly satisfied & 6 & $12 \%$ \\
\hline Satisfied & 19 & $38 \%$ \\
\hline Average & 22 & $44 \%$ \\
\hline Bad & 3 & $6 \%$ \\
\hline Total & 50 & $100 \%$ \\
\hline
\end{tabular}

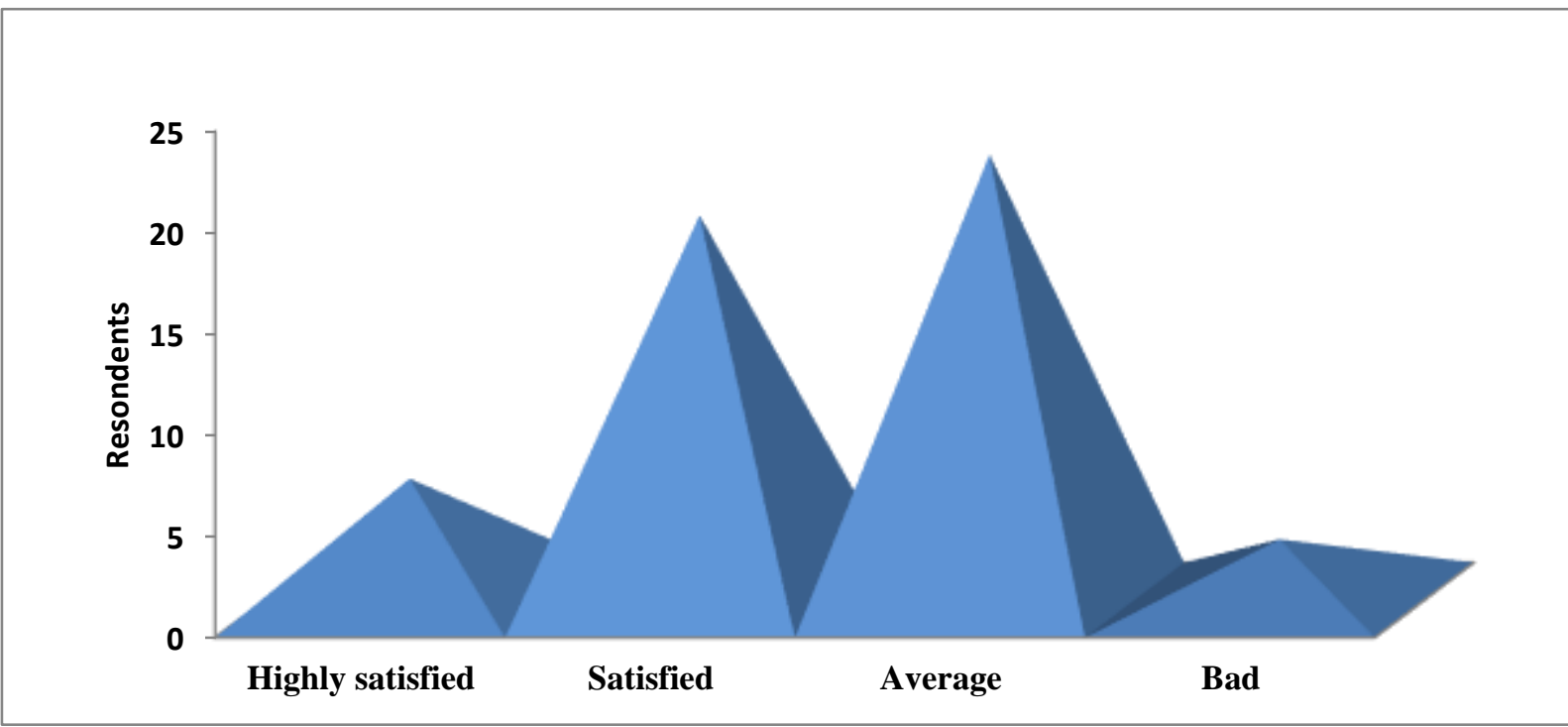

Fig. 12: Product knowledge of sales personnel

\section{Interpretation}

From the above Figure-12, it is clear that $44 \%$ of respondents agree that the knowledge of the sales personnel towards the product is average, $38 \%$ of respondents are satisfied, $12 \%$ of respondents are delighted, and $8 \%$ of respondents are suggesting that product knowledge of the salespersons are bad. Table 13 shows ranking towards store personnel communication fluency.

Table 13: Ranking towards store personnel communication fluency

\begin{tabular}{|l|c|c|}
\hline Particular & No of respondents & Percentage \\
\hline Highly satisfied & 29 & $58 \%$ \\
\hline Satisfied & 12 & $24 \%$ \\
\hline Average & 7 & $14 \%$ \\
\hline Bad & 2 & $4 \%$ \\
\hline Total & 50 & $100 \%$ \\
\hline
\end{tabular}




\section{No of respondents}

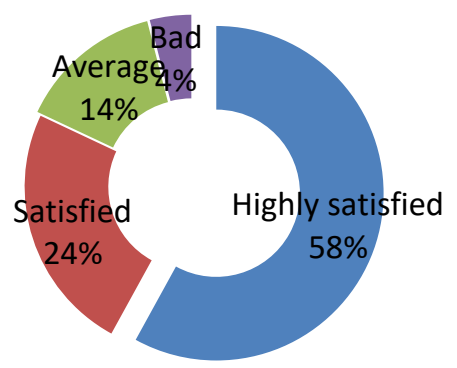

Fig. 13: Ranking towards store personnel communication fluency

\section{Interpretation}

From the above Figure-13, it is clear that 58\% of respondents are delighted with the store personnel communication, $24 \%$ of respondents are satisfied, $14 \%$ of respondents are mentioned as average, and $4 \%$ of respondents are mentioned as communication of the store is agreed as bad. Table 14 shows customer ranking towards salesmanship of store personnel.

Table 14: customer ranking towards salesmanship of store personnel

\begin{tabular}{|l|c|c|}
\hline Particular & No of respondents & Percentage \\
\hline Highly satisfied & 9 & $18 \%$ \\
\hline Satisfied & 19 & $38 \%$ \\
\hline Average & 18 & $36 \%$ \\
\hline Bad & 4 & $8 \%$ \\
\hline Total & 50 & 100 \\
\hline
\end{tabular}

\section{No of respondents}

\#ighly satisfied $\square$ Satisfied $\square$ Average $\square$ Bad

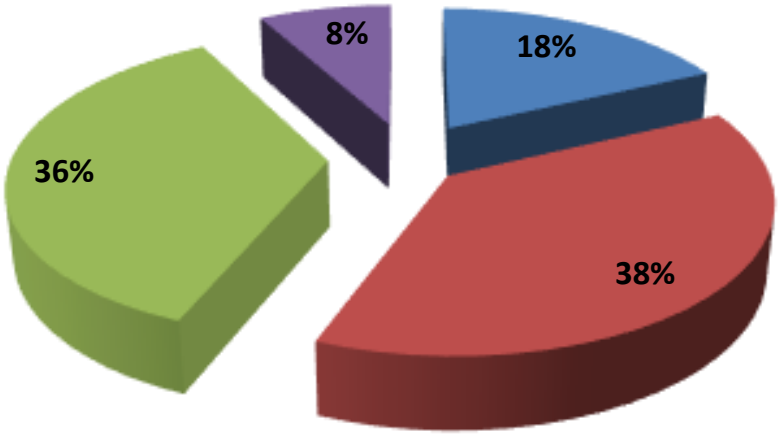

Fig. 14: Customer ranking towards salesmanship of store personnel 
Interpretation

From the above Figure-14, it is clear that $8 \%$ of respondents are highly satisfied with the salesmanship store personnel, $24 \%$ of respondents are satisfied, $14 \%$ of respondents are mentioned as average, and $4 \%$ of respondents are mentioned as salesmanship of the store personnel is agreed as bad. Table- 15 shows whether the signage boards are visible inside the store.

Table 15: Whether the signage boards are visible inside the store

\begin{tabular}{|l|c|c|c|}
\hline \multicolumn{2}{|l|}{ Opinion } & No of respondents & Percentage \\
\hline Yes & 23 & 27 & $54 \%$ \\
\hline No & 50 & \multicolumn{2}{|c|}{$46 \%$} \\
\hline Total & \multicolumn{2}{|c|}{100} \\
\hline
\end{tabular}

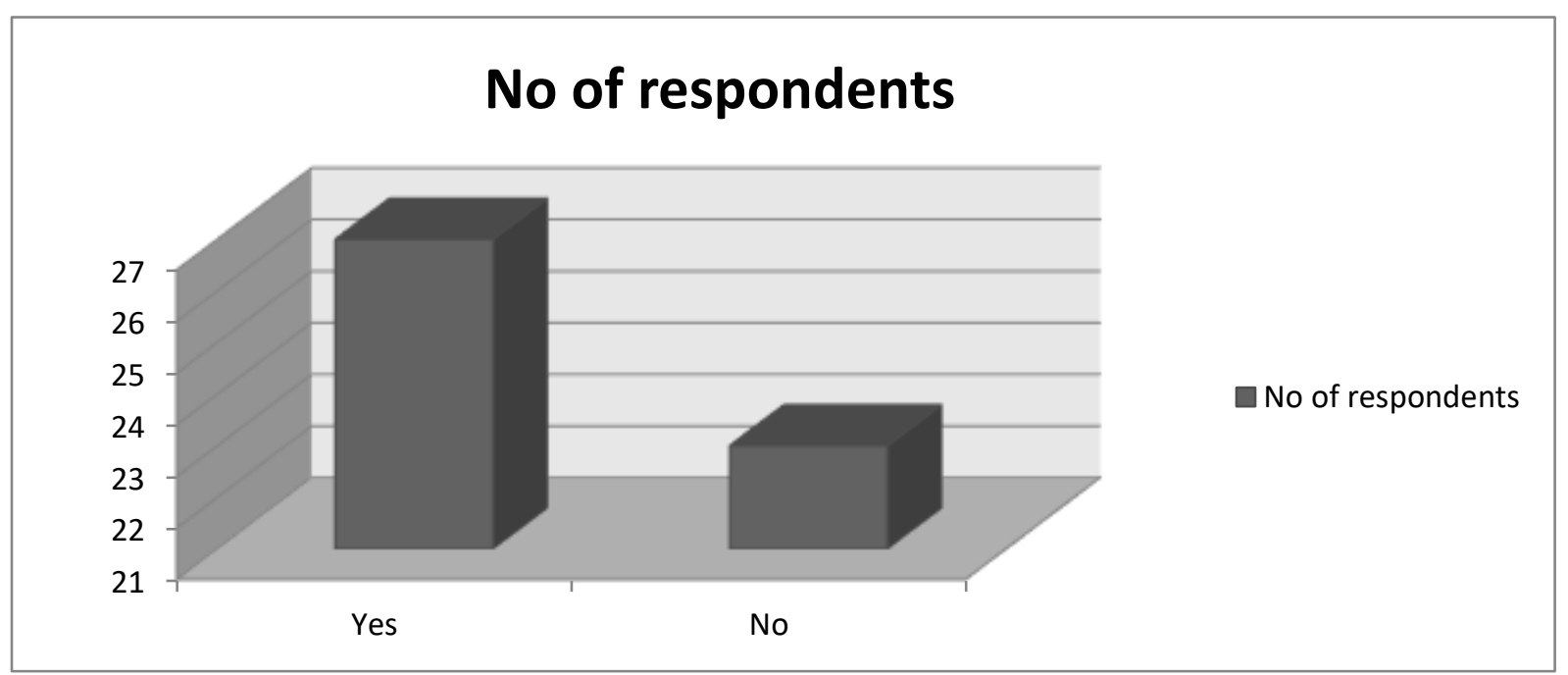

Fig.15: Whether the signage boards are visible inside the store

\section{Interpretation}

From the above Figure-15 it is clear that out of 50 respondents $54 \%$ of respondents have agreed that signage's are visible and rest of the $46 \%$ of respondents agreed that signage's were not visible inside the store. So, it is clear that the store must focus on signage boards. Table-16 shows whether customers are like to visit to the store for repeat purchase and suggest their friends.

Table 16: Would customer are like to visit to the store for repeat purchase and suggest their friends

\begin{tabular}{|l|c|c|}
\hline Particulars & No. of respondents & Percentage \\
\hline Yes & 11 & $22 \%$ \\
\hline No & 7 & $14 \%$ \\
\hline For some extent & 32 & $64 \%$ \\
\hline Total & 50 & 100 \\
\hline
\end{tabular}




\section{NO.of respondents}

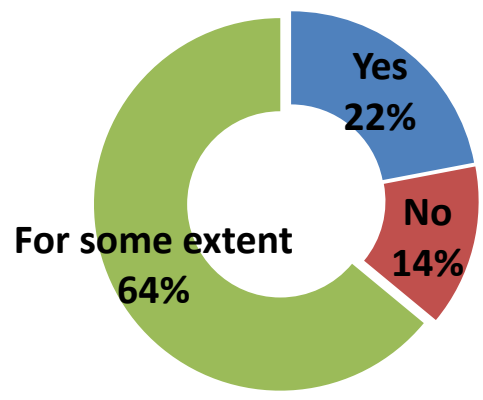

Fig. 16: Would customers are like to visit the store for repeat purchase and suggest their friends

\section{Interpretation}

From the above Figure-16 it is clear that out of 50 respondents $64 \%$ of respondents agreed that customers were like to visit to the store for repeat purchase and suggest their friends, $22 \%$ of respondents were ready to make recommendation and repeat purchase from store, and $14 \%$ of respondents were not are ready to make recommendation and repeat purchase from store.

\section{FINDINGS :}

1. From the study, it is understood that male youngster customers are more frequently visiting to the store.

2. According to the customer opinion, the signage and graphics are not placed in the right position, so they find it difficult to move the concerned department section of the store.

3. Some of the respondents are not regular customers of Reliance Digital store.

4. The respondents have come to know about the existence of the Reliance Digital store only through word-of-mouth communication.

5. According to customer store display is not attractive compared with the leading electronic store in Puttur.

6. The study reveals that the seating arrangement inside the store is not sufficient.

7. The majority of the customer visit the Reliance Digital store with the intention to buy some specific product. Spot purchase activities are happening very rarely.

8. Respondents' perceptions about the various elements of Visual merchandising activities are not satisfactory.

9. Respondent's opinion towards the product knowledge of a sales personnel is not satisfactory.

10. The study makes clear that the various elements of Visual merchandising effect on consumer buying behavior.

11. Apart from Reliance Digital, most of the consumers would like to visit to the Harsha store.

12. Most of the respondents are looking best merchandise from the store.

13. Only to some extent, the respondents are likely to repeat purchases and suggest their friends visit the store.

\section{SUGGESTIONS :}

1. In order to increase the women traffic inside the store, the store must display women fashionrelated categories of the product apart from the product line of Reliance Digital.

2. The store must hold the product relating to the different category of age group people.

3. The store must concentrate on the various signage boards inside the store, and the font size of the board should be visible with some local language to be printed on it.

4. The store has to be made appropriate strategy in order make the consumer visit to the store. It will also focus on peak off sales through some special offers. 
5. The store needs to improve its publicity in order to make the consumer visit to the store. It should concentrate on other various effective media for the promotional activities.

6. The store must make competitor's analysis to face the competition from its rivals.

7. The store must enhance some seating arrangements for the visitor in order to make their shopping activity easy.

8. The store personnel must be strong in terms to make the consumer to change their shopping mentality. They should be able to prevent the wrong perception of the consumer at any point of time.

9. The various elements of Visual merchandising should be considered to be important by highlighting on the various features of the product.

10. The salespersons should be given on the job training to make the consumer provide the necessary information and make sure their queries are answered.

11. Merchandising activities inside the store should be properly maintained. They should always hold excessive stock whenever the consumer comes to the store and ask for a particular product by providing at the point without being delayed.

12. After Sales Service should be very effective, the store should show interest in selling the product and focus on after-sales service. They should make the consumer feel happy then; only it will be possible to create a positive reference group.

\section{CONCLUSION :}

As per the study, it is clear that Visual merchandising plays a vital role in attracting buyers and making them purchase impulsively during their visit. As per the buyer's changing need, the retailer should always try to maximize the quantity of new merchandising relating to the current trend. The store must adopt a congenial store atmosphere to attract a maximum number of customers and retain them for a more extended period. While designing the merchandising presentation, the outlet should focus on various Visual merchandising elements like display screening, store layout, graphics, signage, and other props.

\section{REFERENCES :}

[1] Jasola, M. (2021). Paradigm shift in retail experience and preference of customers in India. Academy of Marketing Studies Journal, 25(2), 1-6. https://www.proquest.com/scholarly-journals/paradigmshift-retail-experience-preference/docview $/ 2516301725 / \mathrm{se}-2$ ?accountid $=166860$

[2] Sumathi, K. (2017). HRD Practices on Employee Engagement: Retail Organizations. SCMS Journal of Indian Management, 14(2), 105-112. https://www.proquest.com/scholarly-journals/hrdpractices-on-employee-engagement-retail/docview/2232616465/se-2?accountid=166860

[3] Phulia, A. B., \& Sharma, M. (2014). Role of retail sector in India. International Journal of Research, $1(2), 150-158$.

[4] Sanjita Bista. (2018). Effective Communication with customers through visual merchandising in physical retail industry. https://www.theseus.fi/bitstream/handle/10024/148226/Bista_Sanjita.pdf?sequence=1\&isAllowe $\mathrm{d}=\mathrm{y}$

[5] Saumya Sinha. (2018, April 16). Through The Looking Glass: Visual Merchandising In A Digital World | Verve Magazine. https://www.vervemagazine.in/travel-and-spaces/through-the-lookingglass-visual-merchandising-in-a-digital-world

[6] Law, D., Wong, C., \& Yip, J. (2012). How does visual merchandising affect consumer affective response? European Journal of Marketing, 46(1/2), 112-133.

[7] Randhawa, K., \& Saluja, R. (2017). Does Visual Merchandising have an Effect on Consumer Impulse Buying Behavior? Journal of General Management Research, 2(3), 34-47.

[8] Soomro, Y. A., Kaimkhani, S. A., \& Iqbal, J. (2017). Effect of visual merchandising elements of retail store on consumer attention. Journal of Business Strategies, 11(1), 21-40.

[9] Khan, S. M. F. A., \& Kumar, D. D. (2016). Influence of Visual Merchandising over Retail Store 
Sales-A Research Report in Indian Context. International Journal of Application or Innovation in Engineering \& Management, 5(5), 12-17.

[10] Zulaikha FATIMA, S., Bisaria, C., \& Prakash, A. (2017). Retailing: An Emerging Trend In IndiaLiterature Review Comercio minorista: una tendencia emergente en la India-revisión de la literatura. Revista ESPACIOS, 38(1), 26-33.

[11] Dale, H. S. (2017). Flagships and visual merchandising: effect of retail store type on shopper response to visual merchandising in the fashion clothing industry. https://ir.canterbury.ac.nz/bitstream/handle/10092/13535/MCom\%20thesis\%20$\% 20$ Hayden\%20Dale.pdf? sequence $=1$.

[12] Chang, H. J., Yan, R.-N., \& Eckman, M. (2014). Moderating effects of situational characteristics on impulse buying. International Journal of Retail \& Distribution Management, 42(4), 298-314.

[13] Tumbe, C., \& Krishnakumar, S. (2018). From bazaar to Big Bazaar: Environmental influences and service innovation in the evolution of retailing in India, c. 1850-2015. Journal of Historical Research in Marketing, 10(3), 312-330.

[14] Upadhyay, D., Jauhari, S., \& Singh, V. (2017). Visual Merchandising: An Integrative Review. Indian Journal of Applied Research, 7(4), 356-359.

[15] Saif, N. M. A., \& Aimin, W. (2016). Exploring the value and process of marketing strategy: Review of literature. International Journal of Management Science and Business Administration, 2(2), 7 18.

[16] Logkizidou, M. (2016). The impact of the visual merchandise display on consumer purchases of luxury brands: the moderating role of cultural capital. Cardiff University.

[17] Kiran, P., \& Mridula, S. (2015). Case Study: Study of visual merchandising and customer needs in visual merchandising for a toys store. Advances in Management, 8(5), 17-21. https://www.proquest.com/scholarly-journals/case-study-visual-merchandising-customerneeds/docview/1678879374/se-2?accountid=166860

[18] Saeed, A. (2015). Impact of lighting as a Visual Merchandising tool on Consumer's Purchase Behaviour. Pakistan Business Review, 17(2), 430-443.

[19] Kumar, A., \& Kim, Y. K. (2014). The store-as-a-brand strategy: The effect of store environment on customer responses. Journal of Retailing and Consumer Services, 21(5), 685-695.

[20] Roxana, O. M., \& Ioan, P. (2013). The effects of ambient scent on consumer behavior: A review of the literature. Annals of the University of Oradea, Economic Science Series, 22(1), 1797-1806.

[21] Mari, M., \& Poggesi, S. (2013). Servicescape cues and customer behavior: a systematic literature review and research agenda. The Service Industries Journal, 33(2), 171-199.

[22] Murray, J., Teller, C., \& Elms, J. (2019). Examining store atmosphere appraisals using parallel approaches from the aesthetics literature. Journal of Marketing Management, 35(9-10), 916-939.

[23] Pillai, R., Iqbal, A., Umer, H., Maqbool, A., \& Sunil, N. (2011). Design, effectiveness and role of visual merchandising in creating customer appeal. MPRA Munich Personal RePEc Archive,1-17.

[24] El-Gohary, H. (2010). E-Marketing-A literature Review from a Small Businesses perspective. International Journal of Business and Social Science, 1(1), 214-244.

[25] Aithal, P. S., \& Kumar, P. M. (2015). Applying SWOC analysis to an institution of higher education. International Journal of Management, IT and Engineering, 5(7), 231-247.

[26] Aithal, P. S. (2017). Industry Analysis-The First Step in Business Management Scholarly Research. International Journal of Case Studies in Business, IT and Education (IJCSBE), 1(1), 113.

[27] Madhushree, R. R., Kumar, A., \& Aithal, P. S. (2018). Business strategy of top Indian IT company: Mindtree. International Journal of Case Studies in Business, IT and Education (IJCSBE), 2(1), 22- 
36.

[28] Aithal, P. S. (2017). Company Analysis-The Beginning Step for Scholarly Research. International Journal of Case Studies in Business, IT and Education (IJCSBE), 1(1), 1-18.

[29] Aithal, P. S. (2017). An effective method of developing business case studies based on company analysis. International Journal of Engineering Research and Modern Education (IJERME), 2(1), $16-27$.

$* * * * * * * * * * * * *$ 